\title{
ПЕДАГОГІЧНЕ УПРАВЛІННЯ ПРОЦЕСОМ ПЕРЕХОДУ ПРОФЕСІЙНО-ОРІЕНТОВАНОЇ ІНФОРМАЦІЇ В РЕЖИМ ПРОЕКТНОЇ ДІЯЛЬНОСТІ ЯК ЗАСІБ ФОРМУВАННЯ ПРОФЕСІЙНОЇ КОМПЕТЕНТНОСТІ В МАЙБУТНІХ ФАХІВЦІВ
}

\author{
Карина Саф'ян \\ кандидат педагогічних наук, доцент \\ Національний університет біоресурсів і природокористування України \\ м. Київ, Україна \\ ORCID ID 0000-0002-6977-9847 \\ kariwka573@gmail.com
}

\begin{abstract}
Анотація. У статті розглянуто педагогічне управління процесом переходу професійно орієнтованої інформації в режим проєктної діяльності як засіб формування професійної компетентності в майбутніх фахівців. Професійно орієнтоване навчання студентів вимагає від них розвитку високого рівня професіоналізму. Управління професійно орієнтованим спрямуванням інформації при підготовці майбутніх учителів філологічних спеціальностей засобами проєктної діяльності - це цілеспрямований процес передавання, засвоєння знань щодо механізмів, правил, норм спілкування (в тому числі й іншомовного), специфіки професійної діяльності й активне становлення особистості майбутнього фахівця, реалізація професійних якостей, здібностей, комунікативних умінь і навичок студента в процесі навчання в закладах вищої освіти. Це формування особистості майбутнього фахівця через систему професійно спрямованих ситуацій і виховання позитивного ставлення до цінностей обраної професії.
\end{abstract}

Ключові слова: управління проєктами; проєкти; професійна підготовка; професійно орієнтоване навчання.

Постановка проблеми в загальному вигляді. Сучасне зрушення в усвідомленні сенсу освіти вбачається в переорієнтації на розвиток здібностей студентів, а передача досвіду уподібнюється засобу чи матеріалу конструювання розвивальних процедур. Нинішні умови вимагають особистості діяльної, спроможної не лише виконувати чиїсь рішення, а й приймати їх самостійно в різних ситуаціях, які часто пов'язані з ризиком, недостатністю інформації, динамічною ринковою кон'юнктурою. Теоретичні за змістом i широкі енциклопедичні знання, які тривалий час були головною метою освітнього процесу, мають стати засобом формування в студента готовності ефективно організувати внутрішні (знання, вміння, цінності, психологічні особливості тощо) і зовнішні (інформаційні, людські, матеріально-фінансові тощо) ресурси для досягнення поставленої мети. Наразі існує потреба суспільства у фахівцях із високим рівнем розвитку професіоналізму, на основі якого вони мають будувати

Професіоналізм педагога: теоретичні й методичні аспекти. - Вип. 11. - Слов’янськ, 2019. 

діяльності як засіб формування професійної компетентності в майбутніх фахівців

відносини в процесі навчання, які розкривають механізм формування професійної компетентності в період навчання у вищій школі.

Аналіз останніх досліджень і публікацій, які розкривають зміст і сутність професійної діяльності педагога (В. Адольф, А. Богуш, Ф. Гоноболін, Е. Карпова, В. Кравцов, Ю. Кулюткін, Л. Спірін, Г. Сухобська та інші); структуру ऑï окремих компонентів (В. Бондар, Л. Ващенко, Н. Кузьміна, А. Ліненко, Г. Нагорна, В. Сластьонін та інші); рівні та форми професійної діяльності (М. Левіна, І. Лернер, В. Паламарчук, Ю. Постолик, Л. Таланова та інші). Ці наукові напрями сформували ключові аспекти змісту й структури професійної підготовки майбутнього вчителя як процесу й результату формування професійної спрямованості й системи професійних знань, умінь і навичок, набуття досвіду теоретичного й практичного вирішення професійних ситуацій і завдань. Професіоналізація навчання іноземної мови ставить за головну мету підготовку майбутнього фахівця, здатного використовувати іноземну мову як інструмент професійної діяльності та професійного пізнання (Т. Алексєєва та Н. Шаболдіна, Г. Вороніна, І. Гевенталь, Н. Гальскова, К. Мільруд, С. Ніколаєва, Г. Рогова, Ф. Рабиновіч, Т. Сахарова та інші).

Формулювання цілей статті. Мета статті - розглянути педагогічне управління процесом переходу професійно орієнтованої інформації в режим проєктної діяльності як засіб формування професійної компетентності в майбутніх фахівців. Професійно орієнтоване навчання студентів вимагає від них розвитку високого рівня професіоналізму. Задачі дослідження: 1) визначити вплив професійно орієнтованого навчання на виконання проєктної діяльності студентів; 2) розглянути комунікативно спрямовану підготовку з іноземного мовлення в закладі вищої освіти; 3) вивчення режиму керування проєктами для визначення й досягнення цілі проєкту.

Методика дослідження полягає в проведенні самооцінки студентами ступеня сформованості провідних якостей, що складають зміст професійної компетентності; за допомогою методу полярних профілів визначався коефіцієнт значущості мотиваційно-ціннісної сфери особистості майбутніх фахівців; самооцінка та експертна оцінка засвоєння професійних знань студентами.

Виклад основного матеріалу. Професійно орієнтована спрямованість навчання - це рівень виконання людиною своїх обов'язків. Вона залежить від: 1) сформованості соціально значущих мотивів діяльності (потреби, інтереси, цінності, погляди); 2) відповідності психофізичних властивостей особистості (здібності), які забезпечують необхідний рівень й ефективність професійної діяльності; 3) розвитку психічних процесів особистості (мислення, пам'ять, 
Педагогічне управління процесом переходу професійно-орієнтованої інформації в режим проєктної діяльності як засіб формування професійної компетентності в майбутніх фахівців

емоції, почуття, воля); 4) повноти та глибини засвоєних спеціальних, психологічних і педагогічних знань, умінь, навичок, тобто набутого досвіду; 5) соціальної активності особистості (Давидов, 1972, с. 86).

Поняття «професійно орієнтоване навчання» часто пов’язують із таким поняттям, як «професійна готовність». У сучасних умовах розвитку й постійного розширення міжнародних контактів іноземна мова стає найважливішим засобом професійного спілкування спеціалістів різних профілів, тому останнім часом в Україні все більше уваги приділяється проблемі викладання іноземних мов 3 урахуванням потреб майбутніх фахівців. Доцільною $\epsilon$ професійна, комунікативно спрямована підготовка з іноземного мовлення в закладі вищої освіти, що припускає формування в студентів здатності іншомовного спілкування в конкретних професійних, ділових, наукових сферах і ситуаціях.

Для того щоб виявити, як впливає наявна система професійної підготовки на стан і динаміку сформованості фахової компетентності майбутніх викладачів професійного спрямування, нами було використано методику експертної оцінки. Вона передбачала самооцінку студентами ступеня сформованості в них провідних якостей, що складають зміст професійної компетентності: мотиваційно-ціннісного, змістового, операційно-діяльнісного, комунікативного й дослідницько-рефлексивного компонентів. За допомогою методу полярних профілів визначався коефіцієнт значущості (К.3.) мотиваційно-ціннісної сфери особистості майбутніх фахівців, який варіює в межах від -1 до +1 . Обробка відповідей студентів подана в табл. 1

Таблицуя 1

\section{Результати сформованості мотиваційно-ціннісного компонента професійної компетентності студентів 4 - 5 курсів}

\begin{tabular}{|c|l|c|}
\hline № & \multicolumn{1}{|c|}{ Ціннісні переваги студентів у педагогічній професії } & К.3. \\
\hline 1 & Можливість виховувати дітей & 0,38 \\
\hline 2 & Можливість займатися самовдосконаленням & 0,28 \\
\hline 3 & $\begin{array}{l}\text { Можливість бачити, спостерігати розвиток дітей, їхні особистісні } \\
\text { зміни }\end{array}$ & 0,34 \\
\hline 4 & Можливість бачити результати педагогічної праці & 0,54 \\
\hline 5 & Суспільне значення роботи вчителя & 0,40 \\
\hline 6 & Відповідність педагогічної роботи моєму характеру & 0,47 \\
\hline 7 & Оцінка власної професійної компетентності & 0,30 \\
\hline 8 & Розв’язання педагогічних ситуацій як творча робота вчителя & 0,48 \\
\hline 9 & Професійна значущість праці вчителя & 0,37 \\
\hline
\end{tabular}

Професіоналізм педагога: теоретичні й методичні аспекти. - Вип. 11. - Слов'янськ, 2019. 
Педагогічне управління процесом переходу професійно-орієнтованої інформації в режим проєктної діяльності як засіб формування професійної компетентності в майбутніх фахівців

Як бачимо, у ціннісних перевагах студентів рідко спостерігаються пріоритети існування в педагога таких важливих якостей особистості, як почуття обов’язку перед суспільством, відповідальне ставлення до виховання доручених учителю дітей, сумлінне ставлення до проведення уроків, чесність при виконання своїх функцій, які становлять фундамент професійної компетентності. Метод полярних профілів дозволив виявити причини такого становища, серед них: побудова навчальних програм, у яких мало часу відводиться на вивчення мотиваційної сфери особистості $(0,82)$, недостатній зв'язок теорії з практикою виховання $(0,81)$, недостатнє вивчення передового педагогічного досвіду з професійного росту особистості вчителя $(0,78)$, під час педагогічної практики недостатньо уваги приділяється моделюванню педагогічних ситуацій на заняттях і виховних заходах $(0,72)$. Бесіди, які були проведені зі студентами та викладачами, показали, що основною причиною низьких результатів $\epsilon$ те, що такий комплекс знань отримувався впродовж лише 2 - 3 лекцій із психолого-педагогічних дисциплін, а цього недостатньо для повноцінного становлення мотиваційно-ціннісної сфери майбутнього професіонала.

Ми запропонували студентам оцінити засвоєні професійні знання щодо діяльності майбутнього викладача за п’ятибальною шкалою. Результати самооцінювання й оцінювання експертами подано в табл. 2.

Таблиия 2

Засвосні професійні знання щодо діяльності майбутнього фахівця

\begin{tabular}{|c|l|c|c|}
\hline$№$ & \multicolumn{1}{|c|}{ Професійні знання } & СО & О \\
\hline 1 & Знання про компетентнісний підхід у навчанні & 2,4 & 2,1 \\
\hline 2 & Сучасні підходи до навчання й виховання в сучасній школі & 2,7 & 2,3 \\
\hline 3 & $\begin{array}{l}\text { 3міст, форми, методи навчально-виховної роботи вчителя- } \\
\text { філолога }\end{array}$ & 3,1 & 3,0 \\
\hline 4 & $\begin{array}{l}\text { Структура, зміст різних типів уроків, методика їх підготовки } \\
\text { та проведення }\end{array}$ & 2,9 & 2,6 \\
\hline 5 & Уявлення про зміст передового педагогічного досвіду & 3,2 & 2,0 \\
\hline 6 & $\begin{array}{l}\text { 3датність успішно взаємодіяти із учнями, колегами та } \\
\text { адміністрацією школи }\end{array}$ & 2,3 & 2,1 \\
\hline 7 & $\begin{array}{l}\text { Стадії розвитку учнівського колективу та виховна робота з } \\
\text { його формування }\end{array}$ & 3,0 & 2,7 \\
\hline 8 & $\begin{array}{l}\text { Знання змісту навчального плану, навчальних програм, } \\
\text { концепцій формування мовної особистості }\end{array}$ & 3,9 \\
\hline
\end{tabular}

() ДВНЗ «Донбаський державний педагогічний університет» 
Педагогічне управління процесом переходу професійно-орієнтованої інформації в режим проєктної діяльності як засіб формування професійної компетентності в майбутніх фахівців

\begin{tabular}{|c|l|c|c|}
\hline 9 & Порядок ведення шкільної документації & 3,3 & 3,2 \\
\hline 10 & Технологія планування виховної роботи & 5,0 & 4,8 \\
\hline 11 & $\begin{array}{l}\text { Здатність вирішувати педагогічні ситуації в навчально- } \\
\text { виховній роботі }\end{array}$ & 2,6 & 2,4 \\
\hline 12 & Стиль спілкування вчителя & 4,1 & 4,0 \\
\hline 13 & $\begin{array}{l}\text { Знання психологічних особливостей учнів різних вікових } \\
\text { груп }\end{array}$ & 3,3 & 3,1 \\
\hline 14 & Специфіка роботи класного керівника & 3,4 & 3,3 \\
\hline \multicolumn{2}{|c|}{ О-оцінка експертною групою викладачів; CO-самооцінка студентами. }
\end{tabular}

Із табл. 2 видно, що засвоєні професійні знання (змістовий компонент професійної компетентності) студентів перебувають переважно на критичному та достатньому рівнях, зокрема: зі структури, змісту різних типів уроків, методики їх підготовки та проведення $(2,9)$; змісту, форм, методів навчальновиховної роботи викладача $(3,1)$; стадії розвитку учнівського колективу та виховної роботи з його формування $(3,0)$. Кращими $\epsilon$ показники 3 технології планування виховної роботи $(5,0)$ і стилів спілкування $(4,1)$. Занепокоєння викликають стан обізнаності студентів у таких напрямах, як-от: сучасні підходи до навчання й виховання учнів $(2,7)$, передовий педагогічний досвід $(3,2)$, специфіка роботи класного керівника $(3,4)$ засвоєні на низькому рівні, а також здатність вирішувати педагогічні ситуації в навчально-виховній роботі $(2,6)$, успішно взаємодіяти 3 учнями, колегами та керівництвом (2,3 б). Окрім того, самооцінка студентами рівня засвоєних знань перевищує оцінку експертів, що свідчить про завищену самооцінку й відповідно про перекручене уявлення про реальність навчально-виховного процесу сучасної школи.

Зміст професійно орієнтованого навчання характеризується розвиненою здатністю до розв'язання професійних ситуацій, розвиненим мисленням i свідомістю. Ми розглядаємо професійно орієнтоване навчання як здатність студента педагогічної вищої школи до самовдосконалення; оволодіння знаннями з філологічних і педагогічних дисциплін; як складне особистісне утворення, що включає в себе структурні компоненти, якості особистості, які впливають на мотиваційну сферу. Зміст професійно орієнтованого навчання становлять соціально значущі мотиви професійної діяльності; педагогічні здібності; повнота, глибина мовленнєвих, філологічних, педагогічних і психологічних знань і вмінь; соціальна активність особистості майбутнього учителя філологічних дисциплін.

Професійна діяльність - це складна динамічна система, що потребує 

діяльності як засіб формування професійної компетентності в майбутніх фахівців

управління. Педагогічне управління специфічне й припускає: з'ясування педагогічних завдань і визначення їхнього місця в загальній системі із забезпечення якості педагогічної діяльності учасників процесу; планування й організація педагогічної роботи; забезпечення систематичного, інтенсивного функціонування педагогічного процесу; підвищення рівня професійної та педагогічної майстерності педагогів; активізацію самовдосконалення.

Виходячи $з$ цього, управлінськими завданнями педагогів є формування в себе педагогічної цілеспрямованості, уміння прогнозувати наслідки прийнятих педагогічних рішень, професійно-педагогічної спрямованості навчання; оволодіння методами й прийомами залучення до творчого пошуку для рішення проблем й оцінки професійних ситуацій; стимулювання активності в усіх видах діяльності; установлення оптимальних строків виконання завдань і доручень, рівня складності й обсягу роботи.

Керування проєктами (англ. project management) - сфера професійної діяльності, під час якої визначаються й досягаються чіткі цілі проєкту при балансуванні між обсягом робіт, ресурсами, часом, якістю й ризиками. Ключовим фактором успіху проєктного керування $є$ наявність чіткого певного плану, мінімізації ризиків і відхилень від плану, ефективного керування змінами, які відбуваються в навчально-виховному процесі сучасної вищої школи (Ньюелл, 2008, с. 416). Майбутній фахівець повинен володіти знаннями у сферах керування конфліктами, комунікації, планування, прийняття рішень тощо. Для ефективної роботи майбутній фахівець повинен адаптуватися до моделей прийняття рішень засобами проєктної діяльності.

Суспільство потребує якісно нового викладача, який може пристосовуватися до сучасних змін, організовувати творчу, інноваційну діяльність у навчальних закладах із використанням проєктних технологій. А проєктна діяльність передбачає розвиток пізнавальних навичок студентів майбутніх учителів - умінь самостійно конструювати свої знання й орієнтуватися в інформаційному просторі, розвиток критичного мислення. Сьогодні проєктування розглядається як особливий вид пізнавальної діяльності та застосовується в системі освіти. Як зазначив О. Коберник, «проєкт $є$ складовою проєктування, що розглядається як створення проєкту (прототипу, прообразу) передбачуваного або можливого об'єкту стану. Проєктування - це вид діяльності, що синтезує в собі елементи ігрової, пізнавальної, ціннісноорієнтаційної, перетворюючої, професійно-трудової, комунікативної, навчальної, теоретичної практичної діяльності» (Коберник, 1998: 23). Отже, володіння проєктною методикою створювання педагогічних ситуацій сприяє 
Педагогічне управління процесом переходу професійно-орієнтованої інформації в режим проєктної діяльності як засіб формування професійної компетентності в майбутніх фахівців

професійному становленню майбутніх учителів.

Описуючи особливу роль методу проєктів у школі, Ю. Олькерс стверджує: «За допомогою методу проектів багато дисциплін можуть бути об’єднані в одному проєкті, а вчителі-предметники одержують додатковий стимул до співробітництва» (Олькерс, 2003, с. 16-38). У процесі роботи над проєктом досягаються дидактичні цілі, вирішується поставлена проблема. Результатом із позиції педагога $є$ зміна рівня сформованості ключових компетенцій, який демонструє студент під час проєктної діяльності (Голуб, Перелигіна, 2003).

У науковій літературі визначено такі вимоги до проєктної технології, як: 1) життєва проблема, пов'язана 3 навчальними цілями; 2) дослідницька діяльність учнів у процесі вирішення проблеми; 3) організація діяльності відповідно до етапів проєктування; 4) формулювання завдань для виявлення навчальної проблеми; 5) постановка проблеми дослідження, пошук шляхів вирішення; створення проєкту; 6) захист; 7) подальше впровадження; самостійність i творчість учнів; 8) практичне або теоретичне значення отриманого продукту з подальшим його впровадженням; розвиток особистості в процесі діяльності (Рожнятовська, Зоц, 2005).

Співпраця викладачів і студентів в умовах здійснення проєктної роботи на заняттях іноземної мови має низку особливостей. Так, щоб сформувати в студентів необхідні вміння та навички в певному виді мовленнєвої діяльності, необхідна активна усна практика для кожного студента групи. Метод проєктів може дозволити вирішити це навчальне завдання, перетворюючи заняття іноземної мови на дискусійний або дослідницький клуб, у якому вирішуються значущі й доступні для студентів проблеми. Для вирішення проблеми, яку покладено в основу проєкту, студентам потрібне не лише знання мови, але й володіння достатнім об’ємом різноманітних практичних знань; студенти повинні володіти певними вміннями: інтелектуальними (робота з інформацією, iii аналіз, узагальнення і висновки), творчими (формулювання мети, варіантів вирішення проблеми, прогноз наслідку запропонованого рішення), комунікативними (ведення дискусії, уміння слухати та чути співрозмовника, висловлювати та відстоювати свою думку) (Самойленко, 2005).

Педагогічна ситуація може бути предметом проєктування. Підкреслимо, що основним змістом проєктувальних дій стають: 1) побудування прогностичної моделі ситуації на підставі теоретичного розуміння іiі природи і структури; 2) проєктування способу відтворення моделі в реальній практиці; 3) багаторазове практичне конструювання ситуації у варіативних умовах; 4) рефлексія з приводу виявлених закономірностей і аналогій (Колесникова, 
Педагогічне управління процесом переходу професійно-орієнтованої інформації в режим проєктної діяльності як засіб формування професійної компетентності в майбутніх фахівців

Горчакова-Сибірська, 2005).

У роботі зі студентами під час проєктування того чи того типу ситуації вона спочатку моделюється викладачем, а потім переноситься в реальну практику за допомогою таких дій: 1) формування домінанти змісту, тобто ціннісно-смислового акценту, що забезпечує вихід на заданий рівень сприйняття та засвоєння запропонованого матеріалу; 2) застосування певної послідовності пред’явлення одиниць змісту, з якими студенти готові та здатні вступити до взаємодії; 3) використання такого способу інтеграції теорії та практики, який дозволить актуалізувати в індивідуальному досвіді отримані знання; 4) формування позицій, які дозволяють «керувати» ступенем активності учасників освітньої взаємодії; 5) гнучкий вибір основи для диференціації аудиторії й оптимального використання форм індивідуально-пошукового руху в освітньому просторі.

Таблиия 3

\section{Діагностичні ситуації}

\begin{tabular}{|c|l|l|}
\hline № & \multicolumn{1}{|c|}{ Види ситуацій } & \multicolumn{1}{|c|}{ Педагогічний смисл ситуацій } \\
\hline 1 & $\begin{array}{l}\text { Ситуація введення } \\
\text { інформації }\end{array}$ & $\begin{array}{l}\text { Забезпечення однозначного й безумовного } \\
\text { розуміння смислу введеної інформації, } \\
\text { попередження їі можливих наслідків }\end{array}$ \\
\hline 2 & $\begin{array}{l}\text { Ситуація формування } \\
\text { досвіду }\end{array}$ & $\begin{array}{l}\text { Придбання досвіду роботи на основі } \\
\text { інформації в різних видах діяльності } \\
\text { (навчальна, імітаційна, професійна) і в різних } \\
\text { системах відносин }\end{array}$ \\
\hline 3 & Орієнтаційна ситуація & $\begin{array}{l}\text { Формування ціннісних орієнтацій, установок, } \\
\text { мотивів по відношенню до запропонованого } \\
\text { змісту навчання; корекція позиції майбутнього } \\
\text { вчителя }\end{array}$ \\
\hline 4 & Емоційні ситуації & $\begin{array}{l}\text { Створення переживань, настрою, емоційного } \\
\text { фону, адекватних запропонованому змісту і } \\
\text { суб'єктивному досвіду студентів }\end{array}$ \\
\hline 5 & Тренінгові ситуації & $\begin{array}{l}\text { Можливість безпосереднього індивідуального } \\
\text { відпрацювання умінь і навичок, які базуються } \\
\text { на одиниці змісту, що вводиться }\end{array}$ \\
\hline 6 & Креативні ситуації & $\begin{array}{l}\text { Створення умов «невизначеності» та виходу на } \\
\text { індивідуально-креативний рівень рішення } \\
\text { проблеми }\end{array}$ \\
\hline
\end{tabular}

(ㄷ ДВНЗ «Донбаський державний педагогічний університет» 
Педагогічне управління процесом переходу професійно-орієнтованої інформації в режим проєктної діяльності як засіб формування професійної компетентності в майбутніх фахівців

\begin{tabular}{|c|l|l|l|}
\hline 7 & Еталонні ситуації & $\begin{array}{l}\text { Пред’явлення зразків оптимальних варіантів, } \\
\text { пов’язаних } 3 \text { даною інформацією дій або } \\
\text { відносин }\end{array}$ \\
\hline 8 & $\begin{array}{l}\text { Ситуація зворотного } \\
\text { зв’язку }\end{array}$ & $\begin{array}{l}\text { Отримання інформації про ефективність } \\
\text { перебігу та засвоєння одиниці змісту, про } \\
\text { правильність обраної стратегії та тактики } \\
\text { роботи з аудиторією }\end{array}$ \\
\hline
\end{tabular}

У дослідженні потрібні педагогічні ситуації створювались завдяки відбору та комбінацій. Наприклад, ситуації введення інформації конструювались за допомогою інформаційного занурення, шляхом знайомства 3 літературою, концентрованої подачі матеріалу; пошуку точок виходу за межі навчального матеріалу, формування «свого питання»; визначення парадигми, у якій сучасна наука описує проблему. Орієнтаційні ситуації створювались завдяки включення до діалогу, дискусії з представниками інших позицій (імітаційна та реальна діяльність), створення банку проблем; конструювання. Емоційні ситуації - під час інтерпретації фрагментів із творів різних жанрів (пісні, вірші, малюнки, музичні замальовки, фотографії тощо); створення низки асоціацій; співпереживання позиції іншої людини, ретроспективи власних переживань.

Висновок з дослідження і перспективи подальших розвідок у цьому напрямі. Управління професійно орієнтованим спрямуванням інформації при підготовці майбутніх учителів філологічних спеціальностей засобами проєктної діяльності - це цілеспрямований процес передавання, засвоєння знань щодо механізмів, правил, норм спілкування (зокрема іншомовного), специфіки професійної діяльності й активне становлення особистості майбутнього фахівця, реалізація професійних якостей, здібностей, комунікативних умінь і навичок студента в процесі навчання в закладах вищої освіти. Це формування особистості майбутнього фахівця через систему професійно спрямованих ситуацій i виховання позитивного ставлення до цінностей обраної професії. Подальшу роботу ми вбачаємо в розробці управлінських проєктів.

\section{СПИСОК ВИКОРИСТАНИХ ДЖЕРЕЛ}

1. Давыдов, В. В. (1972). Виды общения в обучении. Москва: Педагогика.

2. Коберник, С. (1998). Прогнозування виховної ситуації. Педагогіка і психологія, 2, $12-13$.

3. Колесникова, И. А. $\quad$ i $\quad$ Горчакова-Сибирская, М. П. (2005). Педагогическое проектирование. Москва, Российская Федерация: Академия».

4. Голуб, Г. Б., Перелыгина, Е. А. і Чуракова, О. В. (2003). Метод проектов и УМК для сопровождения работы учащихся по методу проектов. Проект подготовлен на основе

Професіоналізм педагога: теоретичні й методичні аспекти. - Вип. 11. - Слов’янськ, 2019. 
Педагогічне управління процесом переходу професійно-орієнтованої інформації в режим проєктної діяльності як засіб формування професійної компетентності в майбутніх фахівців

«Концепции модернизации российского образования до 2010 года». Взято 3 http://www.mega.educat.samara.ru.

5. Ньюэлл, М. В. (2008). Управление проектами для профессионалов. Руководство по подготовке к сдаче сертификационного экзамена. Москва, Российская Федерация: КУДИЦПРЕСС.

6. Олькерс, Ю. (2003). История и польза метода проектов (реферат). Метод проектов: научно-метод. сб. Сер. «Современные технологии университетского образования». Минск, Беларусь: РИВШ БГУ, 2, 16-38. Взято 3 http://charko.narod.ru/ tekst/met pr/ metod_ of_projects.pdf.

7. Самойленко, Н. Б. (2005). Особливості навчання учнів, що виявляють розвинені інтелектуальні здібності. Вісник НТУУ «КПІ». Філософія. Психологія. Педагогіка: зб. наук. праиь, 3(15), 102-108.

8. Рожнятовська, І. і Зоц, В. (2005). Сучасні шкільні технології. Київ, Україна: Радянська школа.

\title{
PEDAGOGICAL MANEGEMENT OF THE PROCESS OF TRANSFERRING PROFESSIONALLY ORIENTED INFORMATION TO THE MODE OF PROJECT ACTIVITIES AS A MEANS OF DEVELOPING FUTURE SPECIALISTS' PROFESSIONAL COMPETENCE
}

\author{
Karyna Safian \\ Candidate of Pedagogical Sciences, Associate Professor of \\ National University of Life and Environmental Sciences of Ukraine \\ Kyiv, Ukraine \\ ORCID ID 0000-0002-6977-9847 \\ kariwka573@gmail.com
}

\begin{abstract}
The article looks into the pedagogical management of the process of transferring professionally oriented information to the mode of project activities as a means of developing future specialists' professional competence. Professionally oriented student education requires the development of a high level of their professionalism. The management of professional guidance in the training of future teachers of philological specialties by means of project activities is a deliberate process of transferring and assimilating of knowledge about mechanisms, rules, norms of communication (including foreign language), specifics of professional activities and active formation of personality of the future specialist, the realization of professional qualities, abilities, communication skills and the students' skills in the process of studying at higher education institutions.

It is the development of the personality of the future specialist through a system of professionally oriented situations and nurturing a positive attitude to the values of the chosen profession. In the current conditions of development and constant expansion of international contacts, foreign language is becoming the most important means of professional communication of specialists of different spheres, so recently in Ukraine, more and more attention is paid to the problem of teaching foreign languages, taking into account the needs of future specialists. It is advisable to have professional, communicative-oriented training in foreign language at a higher education institution, which involves the enhancement of the students' ability to communicate in foreign languages in specific professional, business, scientific spheres and situations.
\end{abstract}

Key words: project management; projects; vocational training; professional-oriented training.

() ДВНЗ «Донбаський державний педагогічний університет» 
Педагогічне управління процесом переходу професійно-орієнтованої інформації в режим проєктної діяльності як засіб формування професійної компетентності в майбутніх фахівців

\section{REFERENCES}

1. Davydov, V. V. (1972). Types of communication in training. Moscow, the Russian Federation: Pedagogika.

2. Kobernik, S. (1998). Predicting the educational situation. Pedahohika i psykholohiia, 2, $12-13$.

3. Kolesnikov, I. A. \& Gorchakova-Siberian, M. P. (2005). Pedagogical design. Moscow, the Russian Federation: Akademiya.

4. Golub, G. B., Perelygin, E. A., \& Churakova, O. V. (2003). Project Method and CMC to support students' project work. The project was prepared on the basis of "Concept of modernization of Russian education until 2010". Retrieved from http://www.mega.educat.samara.ru.

5. Newell, M. W. (2008). Project management for professionals. A guide to preparing for the certification exam. Moscow, the Russian Federation: KUDITS-PRESS

6. Olkers, Y. (2003). History and benefits of the project method (abstract). Project method: scientific method. Sat. Avg. "Modern technologies of university education". Minsk, Belarus: RIVSH BGU, 2, 16-38. Retrieved from http://charko.narod.ru/ text / met_pr / method_of_projects.pdf.

7. Samoilenko, N. B. (2005). Peculiarities of teaching students who show advanced intellectual abilities. Visnyk NTUU "KPI". Filosofiia. Psykholohiia. Pedahohika: zb. nauk. prats, 3(15), 102-108. shkola.

8. Rozhniatovska, I. \& Zots, V. (2005). Modern school technologies, 2. Kyiv, Ukraine: Rad.

Матеріали надійшли до редакції 06.11.2019 р. 